Chirurgia (2020) 115: 656-664

No. 5, September - October

Copyright $\odot$ Celsius

http://dx.doi.org/10.21614/chirurgia.115.5.656

\title{
Posterior Microscopic and Anterior Robotic Assisted STAGED Approach for Voluminous "Dumbbell" Ganglioneuroma - Surgical Technique and Literature Review
}

\author{
Bogdan Smeu', Alina Costache ${ }^{1}$, Bogdan Dumbrava ${ }^{1}$, Ionela Codita ${ }^{2}$, Mihai Cristescu ${ }^{1}$, Cătălin Copăescu ${ }^{1,3 *}$ \\ ${ }^{1}$ Ponderas Academic Hospital Bucharest, Romania \\ 2Elias Hospital, Bucharest, Romania \\ 3"GT Popa" University of Medicine and Pharmacy, Iasi, Romania
}

*Corresponding author: Catalin Copaescu, MD PhD Associated Professor of Surgery Ponderas Academic Hospital Nicolae Caramfil Street, no. 85 A district 1, Bucharest, Romania E-mail: catalin.copaescu@ponderas-ah.ro

Received: 25.08 .2020

Accepted: 10.10 .2020

\section{Rezumat \\ Abord secvențial posterior microscopic și anterior asistat-robotic, pentru tumorile neuroganglionare voluminoase " în clepsidră"- tehnica operatorie și revizuirea literaturii}

Introducere:ganglioneuroamele sunt tumori benigne cu origine în sistemul nervos simpatic, care pot atinge dimensiuni semnificative inainte de a deveni simptomatice.

Scopul:este prezentarea tehnicii de rezecție tumoralã prin abord bipolar, posterior microscopic si anterior asistat robotic pentru ganglioneuroame intravertebrale cu extensie presacratã. Deasemenea, sunt descrise particularitãțile de tratament ale unei paciente de 9 ani cu o astfel de tumorã dezvoltatã anterior de sacru, în care managementul chirurgical a necesitat un abord etapizat bipolar, sub neuromonitorizare directã. Revizuirea literaturii a fost realizatã pe acest subiect.

Metode: abordul neurochirurgical constã în laminectomie S2-S3, rezecția tumorii intracanalare şi intraforaminale şi eventual ligatura şi secționarea rãdãcinii S2. Abordul anterior pentru excizia extensiei pelvine este propus secvențial, prin abord miniminvaziv, folosind platforma roboticã DaVinci XI.

Rezultate: In cazul descris, abordul posterior, neurochirurgical a avut un timp operator de 165 minute, cu o spitalizare de 5 zile, abordul anterior în cea de-a doua etapã a necesitat 660 minute cu 5 zile de spitalizare. $\mathrm{Nu}$ s-au înregistrat complicații postoperatorii iar evoluția postoperatorie a fost favorabilã. Controlul imagistic $(\mathrm{RMN})$ la 6 luni postoperator nu a semnalat recidive locale. 
Concluzii:Abordul posterior vertebral microscopic inițial urmat cel asistat robotic anterior, folosind neuromonitorizare continuã pentru tumorile neuroganglionare voluminoase "în clepsidrã" reprezintã o strategie tehnicã eficientã. Studiile ulterioare vor demonstra aplicabilitatea largã a acestei metode inovatoare.

Cuvinte cheie: ganglioneurom în "clepsidrã", abord chirurgical etapizat, rezecție roboticã, neuromonitorizare

\section{Abstract}

Introduction: ganglioneuromas are benign tumors emerging from the sympathetic nervous system that could grow up to significant sizes before becoming symptomatic.

Aim: to describe the surgical technique of the posterior microscopic and anterior robotic assisted staged approach for voluminous "dumbbell" ganglioneuroma. Besides this, a detailed report of the evolution of 9 years old female patient with such a tumor who underwent a staged bipolar approach, under direct neuromonitoring is presented. The literature has been reviewed on this topic.

Methods: the neurosurgical approach consisted in S2-S3 laminectomy, resecting the intracanalar and intraforaminal S2 tumor, ligating and sectioning the S2 root, the surgical approach was minimally invasive using the DaVinci XI platform for excising the anterior retrorectal extension. Results: As for the posterior surgical stage, the neurosurgical operating time was 165 minutes with a five days hospital stay, and the second anterior surgical staged step took 660 minutes with five days hospital stay. There were no complications in both surgical stages, and the postoperative outcome was uneventful. The 6 months MRI evidenced no recurrency.

Conclusions: the posterior microscopic and anterior robotic-assisted staged approach with continuous neuromonitoring for "dumbbell" ganglioneuroma has proven to be an efficient surgical strategy and technique. Further studies may support the effectiveness of this novel surgical approach and strategy.

Key words: "dumbbell" ganglioneuromas, staged surgical approach, robotic assisted laparoscopic excision, neuromonitoring

\section{Introduction}

Ganglioneuromas are benign tumors emerging from the sympathetic nervous system from the neural crest. Most of them are diagnosed by accident because are usually asymptomatic, tend to grow slowly and stay clinically silent for a long time until they are incidentally discovered or produce mass effect symptoms due to their large size.

They usually developed from neuroblastomas as a primary ganglioneuromas (1). They can be localized anywhere along the sympathetic nervous chain, but more frequent in the posterior mediastinum $(42 \%)$, retroperitoneal $(37.5 \%)$, adrenal glands and cervical (2-5). The presacral development is quite rare, under 20 cases being reported in the literature (6).

The surgical excision is the therapy of choice (7-9). The anterior exclusive approach is mostly reported and a consisted literature is describing the laparoscopic approach $(3,10)$. The robotic assisted surgery makes these complex dissections simpler than conventional laparoscopy $(11,12)$.

We found no report on the bipolar, staged, minimal invasive robotic assisted surgical approach under continuous neuromonitoring 
for "dumbbell" ganglioneuroma.

The aim of our paper to describe the surgical technique of the posterior microscopic and anterior robotic assisted staged approach for voluminous "dumbbell" ganglioneuroma. Besides this, a detailed report of the evolution of a child with such a tumor is presented and the literature has been reviewed on this topic.

\section{Method}

\section{Preoperative Investigations}

Often an incidental discovery during imaging examinations, ganglioneuromas need to be extensively investigated to clearly understand the anatomical implications of its extension. Abdominal Ultrasound (US), Computer Tomography (CT) and Magnetic Resonance Imaging (MRI) are very useful examinations for such patients. MRI offers the most conclusive information related to the tumor's characteristics $(2,8,13)$, while in "dumbbell" tumors brings details about the posterior, intravertebral and the anterior, presacral aspects. The tumor's dimensions, its contour, structure, and invasiveness are carefully noted. A repeated MRI performed at least months later might reveal no interval changes (11). An US or, as we prefer, a CT-guided biopsy of the lesion followed by histological examination may suggest a benign neuronalorigin nerve sheath tumor (Schwannoma-like).

\section{Surgical Excision}

Surgical excision is the treatment for ganglioneuromas. A multidisciplinary discussion of the case is mandatory to plan the therapeutic strategy. The tumor board (TB) should be consisted of spine neurosurgeon, neurologist, radiologist, gastrointestinal surgeon, pediatric surgeon (if the patients is a child) and, anesthetist. An expert in active continuous intraoperative neuromonitoring and a surgical team able to perform advance minimal invasive procedures (microscopic and robotic assisted) is required for the proposed surgical approaches to excise the "dumbbell" tumor.

\section{Surgical Technique}

General anesthesia with orotracheal intubation is required for both the posterior and staged "rendezvous" anterior approach. Surgery is performed with intraoperative neurophysiology monitoring (somatosensory and motor evoked potentials - SSEP and MEP)(12).

\section{Posterior approach}

The posterior approach is the first step of the stagged surgical therapy. The patient is placed in prone position and the tumor's excision is extended inside of the respective foramen, along its anterior extension, toward its presacral aspect. A radiological marker (titanium clip) is placed at the resection margin site. The specimen will be sent for histological examination to confirm the tumor's origin and characteristics.

The Anterior Approach will be planned several weeks after the neurosurgical stage. The minimally invasive robotic assisted approach (DaVinci Xi platform) will be also performed under continuous neuromonitoring. As the histological origin is certified of a benign lesion, penetrating graspers, corkscrew manipulators, or full thickness hanging stitches may be used for traction. The extension of the ganglioneuroma might require the piriform muscle division to get access to its posterior arms and protect the neuronal roots. Splitting the tumor on purpose to protect the surrounded nerves and vessels is histologically permitted for ganglioneuromas and facilitated by the visual accuracy of the Da-Vinci xi robotic platform.

The specimen is placed in an endo-bag and removed throughout a suprapubic minilaparotomy using a wound protector system. Carefully hemostasis and placement of a drainage tube is concluding the surgery.

\section{Postoperative course}

The postoperative course will carefully monitor the patient's evolution focusing on the potential bleeding, thrombotic and neurological complications.

A systematic literature review was 
performed on PubMed and Medline searching for all the reports on ganglioneuroma tumors excision, particularly on the bipolar staged or not anterior and posterior surgical approach.

\section{Results}

A 9 years old female patient was admitted in our hospital for investigations, accusing chronic abdominal pain in the hypogastrium for over 6 months before, limiting the physical activity, sometimes associated with nausea. There was no posterior pain irradiation nor associated neurological symptoms. The abdominal ultrasound identified a large pelvic tumor without being able to determine its origin. Blood test results were normal, including tumoral markers (CEA, CA 19-9, CA 125, AFP). The MRI diagnosed an expansive process originating from the spinal channel (S1-S3) with dural sac and nerve routs stenosis and compression, with an extension throughout the right S2 enlarged foramen into the presacral region where is localized the voluminous extension, up to $10 \mathrm{~cm}$, with inhomogeneous contrast intake. The well-defined thin-walled lesion in the pre-sacral region in the pelvis determined a displacement of rectum and uterus to the left. It appeared benign on MRI and a Schwannoma type tumor was suggested (Fig. 1).

The case was discussed in the Institutional Tumor Board meeting which decided a staged surgical approach as described above. The approval of the Institutional Review Board (IB) has been obtained and the patient and her parents signed a detailed informed consent.

\section{Posterior Approach}

The posterior approach was performed by the spine neurosurgical team. The patient was operated under ventral decubitus and continuous neuromonitoring using the $\mathrm{C}$-arm for guiding and the Zeiss Kinevo 900 micro- $^{-}$ scope. A sagital mediolombar L5-S3 incision was performed. After dissecting the bilateral paravertebral muscles, a S1-S2 laminectomy was performed. A solid white-yellow extradural mass was objectified, severely reducing the spinal canal. An ultrasound dissection was performed just for decompressing and evaluating the relationships with the nervous structures. The S2 right nervous root was undifferentiated from the tumor (originating root) and had no peripheral response when stimulated. This root was ligated preganglionary and resected. The $\mathrm{S} 1$ right
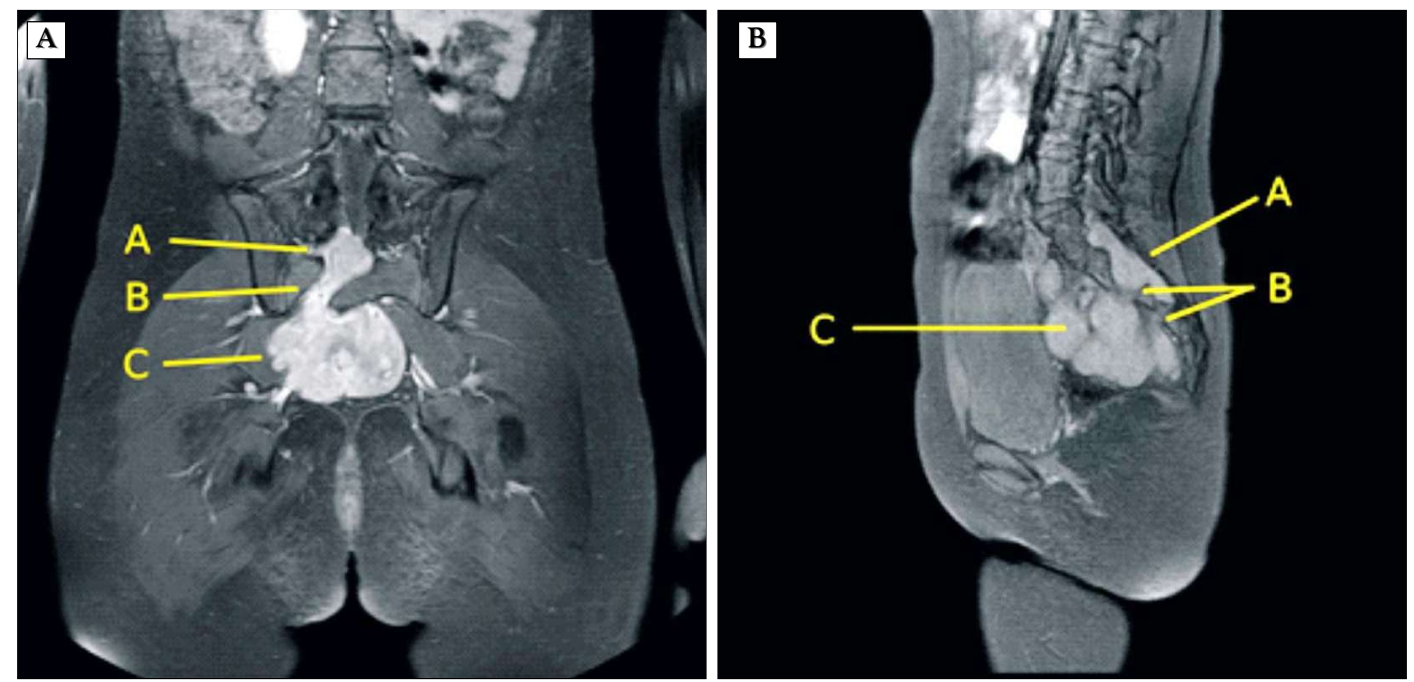

Figure 1. "Dumbbell" Neuroganglioma. MRI aspects of the tumoral extension: frontal (A), sagittal (B).

A - intravertebral extension, B - Extensions throughout sacral foramen, C - presacral, retro-rectal part of the tumor 
nervous root was attached on the tumor but can be safely dissected without peripheral deficiencies during intraoperative stimulating. The right S3 right nervous root was lightly attached to the tumor and could be easily dissected. The rest of the tumor was excised using the ultrasonic/coagulating aspiration and micro-scissors, clearing and recalibrating the spinal canal, the rest of the horse tail roots remaining intact. The tumor was enlarging and leaving the spinal canal through the $\mathrm{S} 1$ and S2 conjugation holes. We completely excised the S1 extension and partially the S2 one where we have left a Titanium clip as a radiological marker and surgical landmark for the consecutive anterior approach (Fig. 2).

The neurosurgical time was 165 minutes, with $75 \mathrm{ml}$ blood loss. The patient was discharged in postoperative day (POD) 4 , encountering five days of hospital stay, without any neurological or local complications. The histopathological result was ganglioneuroma (without any malignancy) (Fig. 3).

\section{Anterior Approach}

Two weeks after the neurosurgical resection, the anterior excision for the presacral component, also under continuous neuromonitoring, using the minimally invasive robotic approach (DaVinci Xi platform). The robotic approach helped us surmount many the intraoperative difficulties related to the large tumor size in a small pelvic space. After creating the pneumo-

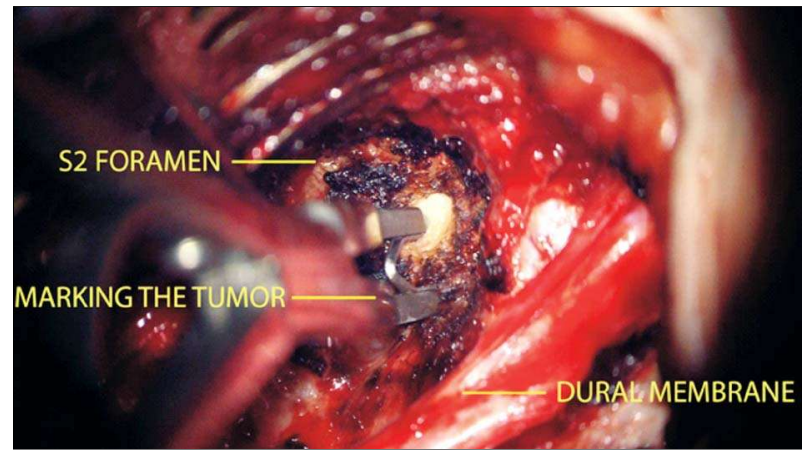

Figure 2. "Dumbbell" Neuroganglioma. Intraoperative aspect during microscopic dissection (Zeiss Kinevo 900). The intravertebral extension has been removed and Titanium clips are placed deep in the $2^{\text {nd }}$ and $3^{\text {rd }}$ Sacral Foramen as a marker for the anterior surgical step

peritoneum using a Veress needle and positioning the optical and working trocars, we have prepared the working space by tilting the table in Trendelenburg position, and, then using trans-parietal stitches to suspended the uterus and annexes (Fig. D). The next step was to dock the DaVinci Xi surgical arms. We started by dissecting the rectum in the mesorectal plane, (Fig. 5) isolating the hypogastric nerves that were suspended on rubber bands (Fig. 6). We then gradually identify a large tumor, with renitent consistency, and started the circumferential dissection, gradually isolating the tumor from the iliac bundles, ureters, and vagina, down to the pelvic floor. The median sacral artery, which was the main tumor feeding vessel, was identified, dissected,
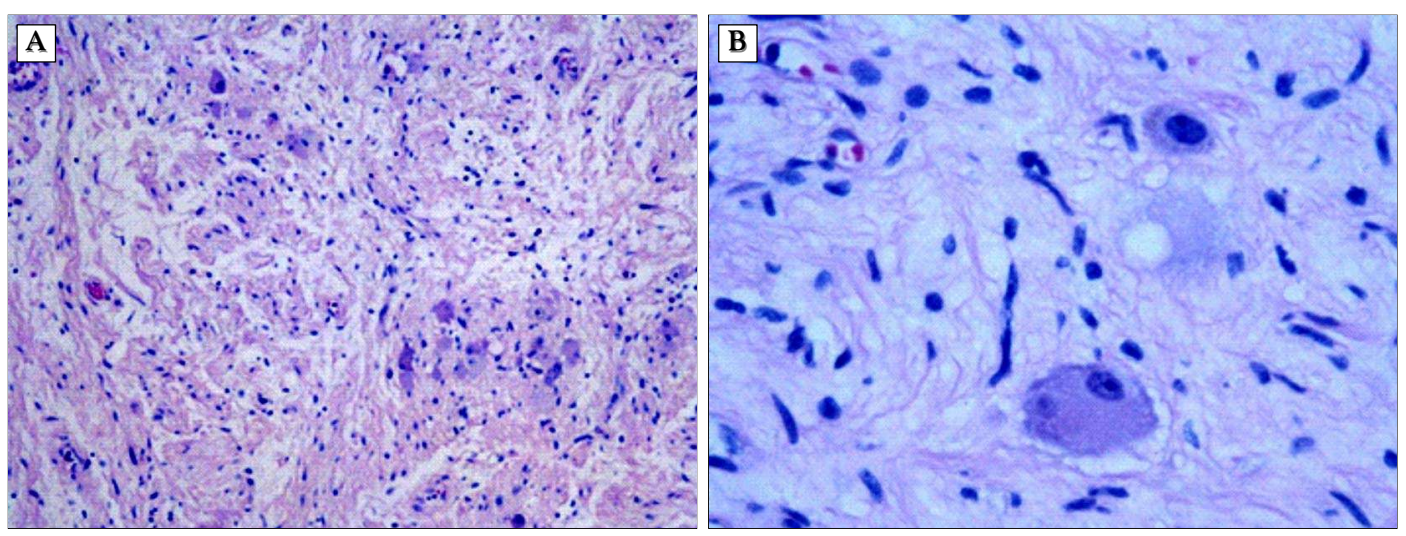

Figure 3. Neuroganglioma. Histological aspect; Schwann cells and round shape ganglia cells 


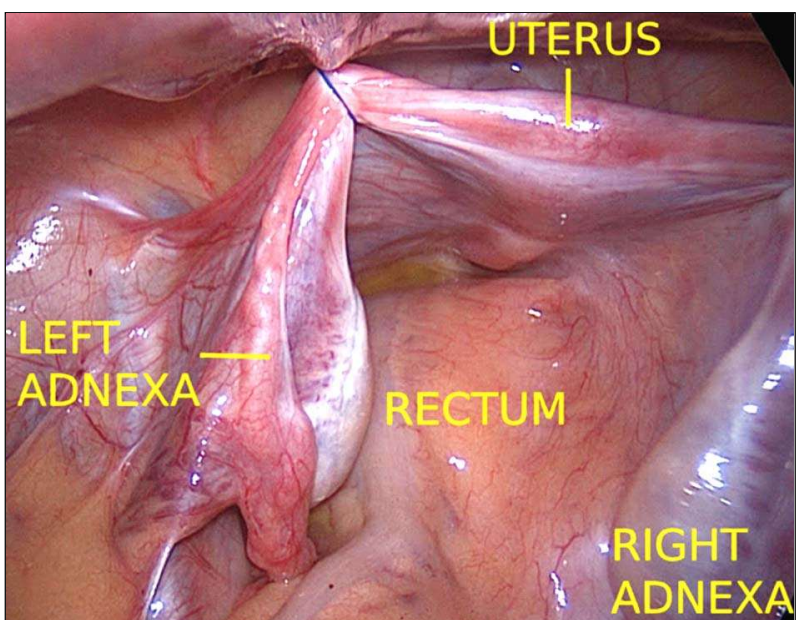

Figure 4. "Dumbbell" Neuroganglioma: the anterior surgical step. Laparoscopic exploration. Uterus and adnexa are suspended with stitches to facilitate the robotic arms access

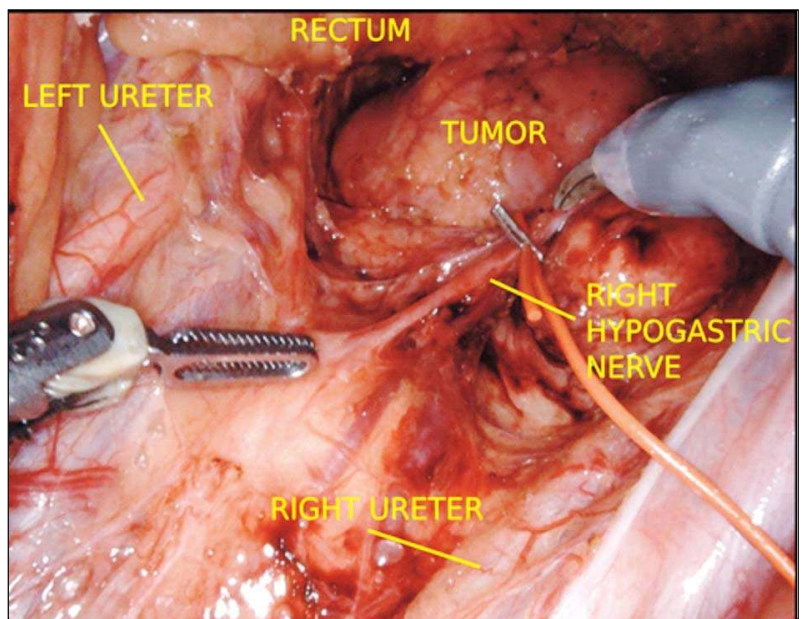

Figure 6. "Dumbbell" Neuroganglioma : the anterior roboticassisted surgical step. The rectum and mesorectum are suspended up; The right and left hypogastric nerves are isolated and suspended with vascular rubber loops; The anterior aspect of the retrorectal tumor demonstrated and the robotic -assisted dissection is carried out.

clipped and divided. The origin of the tumor was confirmed at the right S1-S3 nervous roots. We slowly progress identifying small tumoral extension, medial, infero-lateral and cranial to the right piriform muscle. Knowing the benign histopathology from the previous posterior surgical step we could partially resect the tumor to increase the working space and the mobility for a better understanding of the

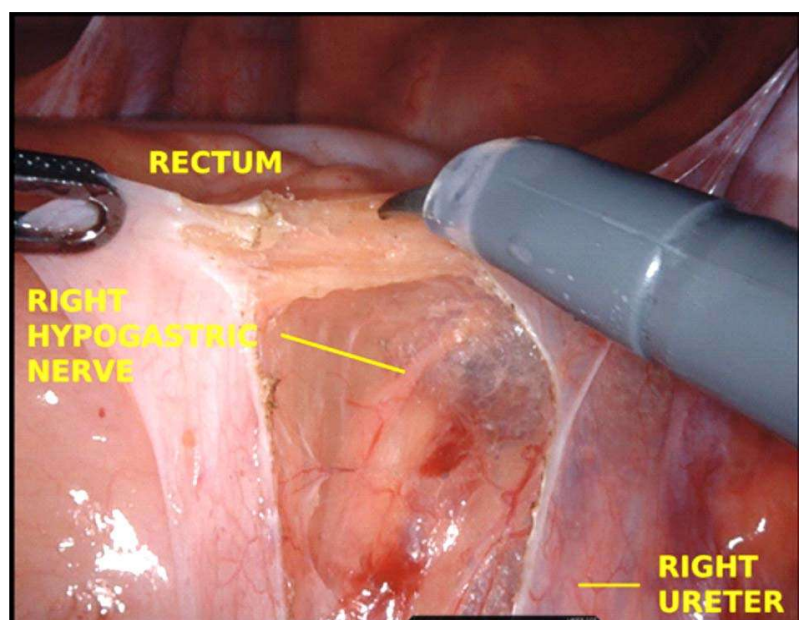

Figure 5. "Dumbbell" Neuroganglioma : the anterior roboticassisted surgical step. The dissection along the mesorectal space is initiated on the right side

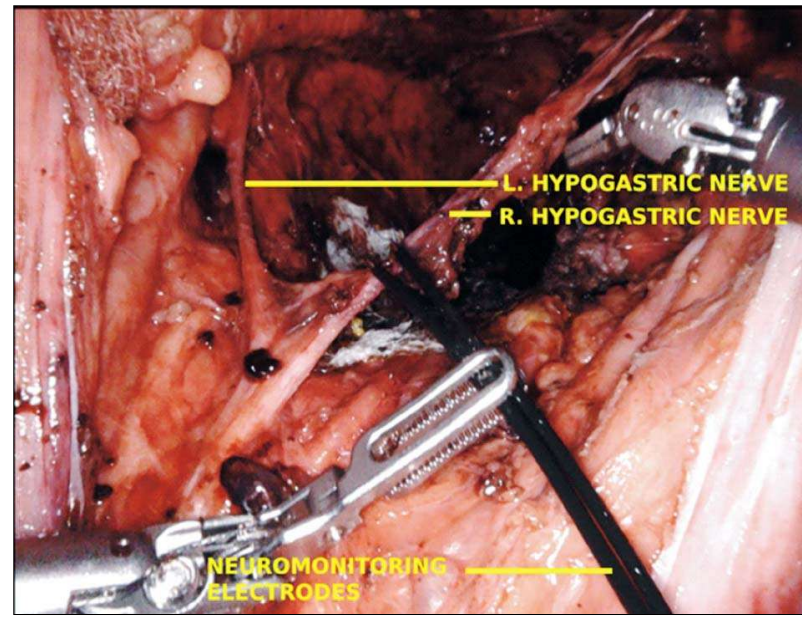

Figure 7. "Dumbbell" Neuroganglioma : Final Aspect of the anterior robotic-assisted surgical step. The tumor has been removed. Rectum is still suspended up. Hemostatic sponge (Tachosil) is applied on the presacral vascular plexus. The Neuromonitoring probe is controlling the hypogastric nerves electrical integrity.

posterior aspect. Because the tumor was wrapping around the right piriform muscle, we had to divide it, thus progressing down to the nervous roots which are gradually identify with the help of the neuromonitoring. We managed to protect the S1-S3 roots by cold sharp dissection with the scissors, maintaining permanently the peripheral electric potentials. We must acknowledge the importance of the 
multidisciplinary team during surgery, the neurophysiologist managing to direct us around the noble nervous structures when the local anatomy was unclear. After completing the resection of the tumor, the hemostasis in the presacral region was completed by applying two hemostatic sponges. The integrity of the piriform muscle was restored by suturing it with resorbable 3.0 stitches. The hypogastric nerves electrical integrity was controlled by using the neuromonitoring probe (Fig. $\nearrow$ ).

Two drainage tubes in the retrorectal space were placed and the specimen was removed throughout a small Pfannenstiel incision, using an endobag and a wound protector. Time of surgery was 660 minutes due to the very challenging posterior dissection and the difficulties of mobilizing such a large tumor in such a small pelvic space of a child. Blood loss was $50 \mathrm{ml}$.

The postoperative course was uneventful, the drainage was removed in the POD 2, and the discharge took place in the POD 4. The postoperative neurological exam was negative for neurophysiological lesions. No fecal continence and control impairment or urinary disfunctions were encountered.

The histopathological and immunohistochemistry exams confirmed the benign findings of the tumor, with the same ganglioneuroma aspects as the first result (Fig. 3).

The postoperative case analyze of the Tumor Board recommended follow-up investigations and monitoring for the next five years. The plan is to perform a MRI and a neurological exam every 6 months up to 3 years, then yearly until 5 years, because in rare cases malign transformations can occur in the ganglioneuromas.

\section{Discussions}

Ganglioneuromas of the sympathetic nervous system were first described in 1870 (14) but the current classification is based on the International Neuroblastoma Pathology Classification System established in 1999 (15). According to this, neuroblastomas, ganglio- neuroblastomas and ganglioneuromas are divided in seven subcategories depending on the morphological characteristics, aiming to obtain a prognosis score. The main difference between those seven subcategories, which explain the clinical evolution and the prognosis, are based on the differentiation degree of the precursor cells.

Ganglioneuromas can be a primary tumor or the result of chemotherapy or radiotherapy of a neuroblastoma or ganglioneuroblastoma. While the neuroblastoma has an unfavorable prognosis, the ganglioneuroma is considered a benign tumor with an excellent prognosis and survival rate. Ganglioneuromas are solid incapsulated tumors, containing ganglion cells, Schwann cells, fibroid tissue and sometimes develops intratumorally calcifications. They are all localized in the paravertebral sympathetic chain (4).

Sometimes the ganglioneuromas can expand throughout the foramen into the spinal channel occupying the epidural space. Those kinds of developments are called "dumb-bell tumors", consisting in an epidural (or extremely rare a subdural) component and an extra-vertebral one $(3,5)$.

In our case, the extra-vertebral component was voluminous, occupying the entire pelvis of a child. Due to the difficulty anticipated in the dissection and the need to completely remove both vertebral and extra-vertebral components, a staged approach was necessary in order to reduce the intraoperative trauma (the cumulated surgery time) and to obtain a needed histopathological result after the first surgical step.

As we have reviewed the literature for similar cased and surgical techniques, we found that the gender distribution is almost the same and the medium diagnosing age is around 6.5 years (1). In the presacral localization the medium diagnosing age is 35.5 years, with patients between 8 and 70 years $(1,2,16)$.

Most patients were asymptomatic, but a series of nonspecific symptoms was described, with lumbar or hip pain, constipation, amenorrhea, sometimes even neurological bladder, most of them justified by the mass 
effect on the vicinity structures.

Hypertension episodes or flushing were described in hormonally active tumors, when we can find plasmatic and urinary high levels of catecholamines $(4,9)$.

The CT scan and MRI are the diagnostic tools available, but they cannot offer details about the differential diagnostic between neuroblastomas, ganglioneuroblastomas and ganglioneuromas. Between those, the MRI has a higher specificity in describing in details the tumor and its important anatomical relationships (7-9).

Fine needle biopsy is a complementary diagnostic tool $(6,8,17)$. when considered necessary; however, in our case, the TB decision was to obtain the histopathological result after the neurosurgical step that was mandatory for releasing the intra-vertebral pressure.

The surgical approach is the only option for this kind of cases (2). As the ganglioneuromas are a rare pathology, with a difficult surgical approach due to its origin, some algorithms were proposed for reducing the intraoperative and postoperative complications. According with them $(9,17,18)$ is better to excise tumors above $\mathrm{S} 3$ by abdominal approach, and posterior or combined approach is more feasible for tumors below S3.

In our case, the tumor was situated between S1 and S3 with compression and stenosis of the dural sac and nervous roots, with an anterior extension throughout S2 right foramen into the presacral space, motivating our combined multidisciplinary approach.

Prognosis after the complete resection of the ganglioneuroma is excellent and it was demonstrated in our case two. The $3^{-}$and $6^{-}$ months MRI revealed no local recurrency. Due to the benign findings during histopathological exam the patient did not required postoperative chemotherapy or radiotherapy.

The number of presacral ganglioneuromas found in literature is under $20(2,10,16,19)$, this localization posing a challenging management for the surgical team due to the confined working space. Most of the cases were solved only by an open anterior approach which led to the delay in the patients' recovery with a longer hospitalization, and probably more important with intraoperative difficulties in identifying sensible nervous structures, increasing the chance for intra and postoperative complications.

The robotic assisted minimally invasive retroperitoneal ganglioneuroma excision was mentioned in a limited number of publications $(11,12,19)$. The authors did not encounter all the difficulties secondary of working in a confined pelvic space of a child hosting a large tumor as in our case, because they managed to obtain a large working space. There was no report of bipolar, even staged, posterior and anterior approach in these articles.

The strength of our report is to describe a novel staged surgical technique of excising a voluminous "dumb-bell" ganglioneuroma, using microscopy for the posterior extension and minimally invasive robotic-assisted surgery for the anterior extension, both under continuous neuromonitoring. As several articles are reporting the use of robotic technology for the retro-rectal tumors $(5,8,11,12,19)$ we found none referring to a similar bipolar staged strategy, neither using robotic assisted surgery for dumbbell tumors nor for ganglioneuroma. The limitation of the study is related to the reduced number of cases.

\section{Conclusions}

The posterior microscopic and anterior roboticassisted staged approach with continuous neuromonitoring for "dumbbell" ganglioneuroma has proven to be an efficient surgical strategy and technique. Further studies may support the effectiveness of this novel surgical approach and strategy.

\section{Conflict of Interest}

The authors declare no conflicts of interests.

\section{Ethics Approval}

All procedures performed in studies involving human participants were in accordance with 
the ethical standards of the 1964 Helsinki Declaration and its later amendments or comparable ethical standards.

\section{Reference}

1. Geoerger B, Hero B, Harms D, Grebe J, Scheidhauer K, Berthold F. Metabolic activity and clinical features of primary ganglioneuromas. Cancer. 2001;91(10):1905-13.

2. Cerullo G, Marrelli D, Rampone B, Miracco C, Caruso S, Di Martino $\mathrm{M}$, et al. Presacral ganglioneuroma: a case report and review of literature. World J Gastroenterol. 2007;13(14):2129-31.

3. Lee MT, Panbehchi S, Sinha P, Rao J, Chiverton N, Ivanov M. Giant spinal nerve sheath tumours - Surgical challenges: case series and literature review. Br J Neurosurg. 2019; 33(5):541-549.

4. Vardas K, Manganas D, Papadimitriou G, Vougas V, Bakalis A, Chantziara $\mathrm{M}$, et al. Presacral ganglioneuroma: diagnostic considerations and therapeutic strategy. Case Rep Oncol. 2013; 6(3):561-8.

5. Wewel JT, Kasliwal MK, Chmielewski GW, O'Toole JE. Complete anterior-posterior minimally invasive thoracoscopic robotic-assisted and posterior tubular approach for resection of thoracic dumbbell tumor. J Craniovertebr Junction Spine. 2020;11(2):148-151.

6. Lynch NP, Neary PM, Fitzgibbon JF, Andrews EJ. Successfu management of presacral ganglioneuroma: A case report and a review of the literature. Int J Surg Case Rep. 2013:4(10):933-5.

7. Kołodziejski LS, Dyczek ST, Pogodzinski M. Surgical management of retrorectal tumors. J Chir (Paris). 2004;141(2):109-13. French

8. Toh JW, Morgan M. Management approach and surgical strategies for retrorectal tumours: a systematic review. Colorectal Dis. 2016; 18(4):337-50
9. Woodfield JC, Chalmers AG, Phillips N, Sagar PM. Algorithms for the surgical management of retrorectal tumours. Br J Surg. 2008; 95(2):214-21.

10. Shi C, Li F, Wang Y, Pei L, Wang T. Retroperitoneoscopic resection of retroperitoneal nonadrenal ganglioneuromas: our technique and clinical outcomes. Int Braz J Urol. 2018;44(6):1166-1173.

11. Palep JH, Mistry S, Kumar A, Munshi M, Puranik M, Pednekar A. Robotic excision of a pre-coccygeal nerve root tumor. J Minim Access Surg. 2015;11(1):103-5.

12. Garzon-Muvdi T, Belzberg A, Allaf ME, Wolinsky J-P. Intraoperative nerve monitoring in robotic-assisted resection of presacral ganglioneuroma: Operative Technique. Oper Neurosurg (Hagerstown). 2019;16(1):103-110.

13. Yalav 0, Topal U, Eray İC, Deveci MA, Gencel E, Rencuzogullari A. Retrorectal tumor: a single-center 10-years' experience. Ann Surg Treat Res. 2020;99(2):110-117. Epub 2020 Jul 31.

14. Leeson MC, Hite M. Ganglioneuroma of the sacrum. Clin Orthop Relat Res. 1989;(246):102-5.

15. Shimada H. The International Neuroblastoma Pathology Classification. Pathologica. 2003;95(5):240-1.

16. Chéreau N, Lefevre JH, Meurette G, Mourra N, Shields C, Parc Y, et al. Surgical resection of retrorectal tumours in adults: long-term results in 47 patients. Colorectal Dis. 2013;15(8):e476-82.

17. Macafee DAL, Sagar PM, El-Khoury T, Hyland R. Retrorectal tumours: optimization of surgical approach and outcome. Colorectal Dis. 2012;14(11):1411-7.

18. Buchs N, Taylor S, Roche B. The posterior approach for low retrorectal tumors in adults. Int J Colorectal Dis. 2007;22(4):3815. Epub 2006 Aug 15

19. Burttet L, da Silva Abreu FJ, Varaschin GA, Neto BS, Berger M. Robotic assisted laparoscopic excision of a retroperitoneal Ganglioneuroma. Int Braz J Urol. 2017;43(5):997. 